\title{
熱伝達係数が変化する場合の熱過渡応力の近似評価法*
}

\author{
古 橋一 郎*1, 笠 原 直 ${ }^{* 2}$, 柴 本 宏*2

\section{Approximate Evaluation Method of Thermal Transient Stress under Variable Heat Transfer Coefficient} \\ Ichiro FURUHASHI*3, Naoto KASAHARA and Hiroshi SHIBAMOTO \\ *3. Japan Nuclear Cycle Development Institute, \\ 4002 Narita-cho, Higashi-Ibaraki-gun, O-arai-machi, Ibaraki, 311-1393 Japan

\begin{abstract}
The new approximate evaluation method was proposed for thermal transient stress under variable heat transfer coefficient. The proposed method uses Green functions and convolution integral. The proposed method was applied to the calculations of thermal transient stresses of a skirt ${ }^{-}$structure and a tube-sheet structure of IHX (intermediate heat exchanger) in commercialized fast reactor. It was verified that the proposed method gave good estimations for thermal transient stresses of those structures
\end{abstract}

Key Words: Thermal Transient Stress, Variable Heat Transfer Coefficient, Approximate Evaluation, Green Function, Convolution Integral, Screening, FBR, IHX, Skirt Structure, Tube-sheet Structure

\section{1. 粕}

ナトリウム冷却型実用高速炉では, 信頼性を確保し つつ, 経済性を向上させるためコンパクトな原子炕構造, 短縮した主配管, 主循環ポンプ組込型の中間熱交換器 (IHX)，ループ数削減が検討されている. これらの設計 合理化に伴い, 冷去材の総量が咸少し, 出力変動に伴う 温度変化が大きくなり，熱過渡荷重が厳しくなる傾向に ある.このため, 多種類の熱過渡事象がある場合に設計 上厳しい事象を選定する, また, ある熱過渡事象に対し 熱応力が厳しい部位を摘出するスクリーニング法いか望 まれている.

流体と熱伝達にある構造物において，材料特性が定 数で熱伝详係数が部分表面毎に定数である場合, 熱伝導 の支配方程式および境界条件は定係数の線形偏微分方程 式となる.このような線形系では「重ね合わせの原理」 が成立し Green 関数が存在する. Green 関数か溉知なら ば, 任意の流体温度変化による熱過渡応力を畳み込み積 分(Green 関数法)により計算できる. 多数の熱過渡事象 を効率良く評価でき，スクリーニンク評価あるいはオン ライン熱応力評価などに応用できる利点があるめ。

高速炉の設計で想定される熱過渡事象には, 低確率 の事故事象など, 定格運転から大きく逸脱する事象も含

* 原稿受付 2005 年 8 月 25 日.

*1 正員. (株)CRCソリューションズ(『136-8581 東京都江東 区南砂 2-7-5) [核燃料サイクル開発機構(派遣) (画3111393 茨城県東茨城郡大洗町成田町 4002)].

*2 正員, 核燃料サイクル開発機構大洗工学センター.

E-mail : furuhashi.ichiro@ jaea.go.jp
まれる. 構造設計では, 冷却材の温度と流量が同時に急 変するような事象も評価する必要がある．流量が変化す ると熱伝澾係数が変化し, 境界条件は係数が変化する偏 微分方程式となる. 以後これを係数変化熱応力と記す. 俰数変化熱灾力の理論的な解析例として, 熱伝達保数が

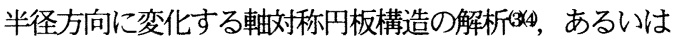
熱伝達係数が時間変化する平板構造の解析副などがある.

本報告では，理論解析の適用が難しい現実構造物に おいて, FEM 数值解析による変形数熱応力問題の近似 評価法について論じる. 従来の係数変化熱応力の評価は, 熱伝详係数変化を考慮した FEM 解析（以後は係数変化 FEM 解析之記す），あるいは最大流量時の上限熱伝達 係数を維持する線形近似モデルによる FEM 解析（以後 は上限係数 FEM 解析と記す) によった場合が多い，係 数変化 FEM 解析は解析コストが大きいという久点があ る. また結果が予測できないので, 熱過渡条件等が変更 された時の予測および感度評価に適さない，上限係数 FEM 解析は熱応力を過大評価する場合が多いという久 点があり, 設計合理化が期待できない. 本報告ではこの ような倸数変化熱応力に対し, 数種類の Green関数を用 いて畳み込み積分を応用した工学的な近似計算手法を提 案し，その有効性を検証する. また提案手法の熱過渡応 カスクリーニング法への応用, 熱過渡応力のパラメータ 感度評価あるいはオンライン高速評価などへの応用につ いて検討する.

2. 計算手法 
21 Green 関数法 構造の材料特性を定数とし, 初 期状態は全体が一様温度 $\mathrm{T}_{0}$ て熱応力 0 とする. 部分表 面 $\mathrm{Si}$ で流体 i と熱伝達状態にあり, 熱伝達俰数を定数 hi とし，流体温度を $\mathrm{Fi}(\mathrm{t})$ とする( $(\mathrm{i} 1, \mathrm{~N})$. 流体 $\mathrm{k}$ の温度のみ ステップ変化 $\left[\mathrm{F}_{\mathrm{k}}=\mathrm{T}_{0}+1(\mathrm{t}>0)\right] し$, 他の流体 $\mathrm{j}$ の温度は $\mathrm{T}_{0}$ を維持した場合 $[\mathrm{F} j=\mathrm{T} / \mathrm{j} \neq \mathrm{k})]$ の, 構造の任意位置 $\mathrm{P}$ の熱 応力は流体 $\mathrm{k}$ のステップ温度変化に対する Gren 関数で あり、これを $\mathrm{G}_{\mathrm{k}}\left(\mathrm{P}, \mathrm{h}_{1}, \mathrm{~h}_{2}, \mathrm{t}\right)$ と表わす.

流体 $\mathrm{k}$ の温度が $\mathrm{F}(\mathrm{t})$ と時間変化し, 他の流体 $\mathrm{j}$ の温度 は基準温度 $\mathrm{T}_{0}$ を維持した場合とする. 初期状態は時間 $\mathrm{t}$ $=0$ まで $\mathrm{F}_{\mathrm{k}}(0)$ か維持された定常熱応力状態とする. 熱応 力は次式の畳み込み積分で与えられる。

$$
\begin{aligned}
& S_{k}(P, t)=\left\{F_{k}(0)-T_{0}\right\} G_{k}\left(P, h_{1}, h_{2},,, \infty\right) \\
& +\int_{0}^{t} F_{k}{ }^{\prime}(\tau) G_{k}\left(P, h_{1}, h_{2},,, t-\tau\right) d \tau
\end{aligned}
$$

右辺第 1 項が初期定常熱応力を表わしている. 各流体 温度がそれぞれ時間変化した場合の熱応力 $\mathrm{S}(\mathrm{P}, \mathrm{t})$ は, 各 流体の温度変化による熱応力を(1)式で計算し, それらを 全流体について加算する.

$$
S(P, t)=\sum_{k=1}^{N} S_{k}(P, t)
$$

ここで $\mathrm{N}$ は流体の総数である. なお流体 $\mathrm{i}$ との熱伝達係 数を単一の定数 $\mathrm{h}_{\mathrm{i}}$ としたが, 複数の部分表面 $\mathrm{S}$ 无こにに 異なる定数 $h_{\text {h }}$ であってもよい. 32 節ではこのような場 合を取り扱う.

\section{2 熱伝道保数力瘁化する場合の熱過痕応力の近似計算}

法熱伝達俰数力洔間变化する場合, 熱過渡応力の 応答関数は流体温度か湾化する時刻 $\tau$ に依存した関数と なり，畳み込み積分 [(1)式の右辺第 2 項 $]$ が適用できな い.このような係数変化熱応力に対し, 畳み込み積分を 応用した近似計算法を提案する.

流体 $\mathrm{i}$ との熱伝達係数を $\mathrm{h}(\mathrm{t})$ と表す $(\mathrm{i}=1, \mathrm{~N})$. 流体 $\mathrm{k}$ の 温度のみ $\mathrm{F}_{\mathrm{k}}(\mathrm{t})$ と変化し, 他の流体 $\mathrm{j}$ の温度は $\mathrm{F}(\mathrm{t})=\mathrm{T}_{0}$ を維 持する場合の熱応力を考える $(\mathrm{j} \neq \mathrm{k})$. 初期状態は時間 $\mathrm{t}=0$ まで $h(0)$ およ゙ $\mathrm{F}(0)$ が維持された定常熱応力状態と する. 初期定常熱応力は(1)式の右辺第 1 項の $h_{i}$ をh $(0)$ に 置き換えたものとなる. (1)式の右辺第 2 項の積分の中は, 微小時間区間 $[\tau, \tau+\mathrm{d} \tau]$ の流体温度变化 $\mathrm{F}_{\mathrm{k}}(\tau) \mathrm{d} \tau$ により 時間 $\mathrm{t}$ に生じる熱応をを表わす。これを時間区間 $[\tau, \mathrm{t}]$ の 平均熱伝達係数に対する Green 関数で近似すると, $\mathrm{S}_{k}(\mathrm{P}, \mathrm{t})$ の近似式として次式が得られる.

$$
\begin{aligned}
& S_{k}(P, t)=\left\{F_{k}(0)-T_{0}\right\} G_{k}\left\{P, h_{1}(0), h_{2}(0),,, \infty\right\} \\
& +\int_{0}^{1} F_{k}{ }^{\prime}(\tau) G_{k}\left\{P, \overline{h_{1}(\tau, t)}, \overline{h_{2}(\tau, t)},,, t-\tau\right\} d \tau
\end{aligned}
$$

ここで上線付き $\mathrm{h}(\tau$ ，无は時間区間の平均熱伝達係数 を表す，ある時間 tた に熱伝達係数が ho(t) に，流体温度
が $\mathrm{T}_{0}$ になったとする. 以後この状態を維持する場合を 考える. $\mathrm{t} \rightarrow \infty$ で一様基準温度 $\mathrm{T}$, 熱㐫力 0 となるが, 近似式(3)は次式に漸近する.

$S_{k}(P, t=\infty)=\left\{F_{k}(0)-T_{0}\right\} G_{k}\left\{P, h_{1}(0), h_{2}(0),,, \infty\right\}_{(4)}$ $+\left\{T_{0}-F_{k}(0)\right\} G_{k}\left\{P, h_{1}\left(t_{E}\right), h_{2}\left(t_{E}\right),,, \infty\right\}$

定常值 $\mathrm{G}_{\mathrm{k}}\left(\mathrm{P}, \mathrm{h}_{1}, \mathrm{~h}_{2}, \infty\right)$ 为熱伝達俰数 $\mathrm{h}_{\mathrm{j}}$ に依存しない構 造では(4)式 $=0$ となり, 近似式(3)は $t \rightarrow \infty$ で正解に漸近 する. 一方, 定常值力熱伝详係数に依存する構造では(4) 式 $\neq 0$ となり, 近似式(3)は $\mapsto \infty$ で一定の誤差を与える. これを補正するため, 初期定常熱応力項が (熱伝達係数 変化に応じて）変化する時定数を $\tau_{\mathrm{P}}$ として, $\mathrm{S}_{\mathrm{k}}(\mathrm{P}, \mathrm{t})$ を次 式により近似する。

$$
\begin{aligned}
& S_{k}(P, t)=\left\{F_{k}(0)-T_{0}\right\}\left[G_{k}\left\{P, h_{1}(0), h_{2}(0),,, \infty\right\} \exp \left(-t / \tau_{P}\right)(5)\right. \\
& \left.+G_{k}\left\{P, \overline{h_{1}(0, t)}, \overline{h_{2}(0, t)},,, \infty\right\}\left\{1-\exp \left(-t / \tau_{P}\right)\right\}\right] \\
& +\int_{0}^{1} F_{k}^{\prime}(\tau) G_{k}\left\{P, \overline{h_{1}(\tau, t)}, \overline{h_{2}(\tau, t)},,, t-\tau\right\} d \tau
\end{aligned}
$$

各流体の温度がそれぞれ同時に時間変化する場合の 構造の熱応力 S(P,t)は、各流体の温度変化による熱忘力 を(5)式で近似計算し，それらを(2)式により加算する.

23 工学的な近似計算法近似式(5)では任意の熱伝 達係数に対する Green 関数が使用される. これを効率よ く近似計算するには熱伝達係数の変動範囲内の何点力の 值に対して, Green 関数を予め求めておき, それらを $\mathrm{h}_{\mathrm{j}}$ に関して線形補間するのが実用的である. 例えば hs(t)の 最大值 $h_{\text {mimax }}$ 中間値 $h_{\text {imed }}$ および最小值 $h_{\text {minin }}$ に対して Green 関数を求めておき，それらを hに対して線形補間 する. また近似式(5)の右辺の積分は，時間を有限区間に 分割して積算するのが実用的である. 例えば時間 $\mathrm{t}$, 流 体 $\mathrm{k}$ の温度 $\mathrm{F}_{\mathrm{k}}(\mathrm{t})$ およひ熱伝達俰数 $\mathrm{h}_{\mathrm{k}}(\mathrm{t})$ カ時系列デー夕点 $\left(\mathrm{t}_{j} \mathrm{~F}_{\mathrm{k}_{j}} \mathrm{~h}_{\mathrm{k}}\right)(\mathrm{j}=1, n)$ による多直線で与えられた場合, 積分を次 式で近似計算する.

$\int_{0}^{1} F_{k^{\prime}}(\tau) G_{k}\left\{P, \overline{h_{1}(\tau, t)}, \overline{h_{2}(\tau, t)},,, t-\tau\right\} d \tau$

$=\sum_{j=1}^{m-1}\left(F_{k, j+1}-F_{k, j}\right) G_{k}\left\{P, \overline{h_{1}\left(t_{j}, t_{m}\right)}, \overline{h_{2}\left(t_{j}, t_{m}\right)},, t-\frac{t_{j}+t_{j+1}}{2}\right\}$

(for $\left.t_{m} \leq t\right)$

ここで時間幅 $\left(\mathrm{t}_{\mathrm{j}+1}\right.$ 一七)は限界值を超えると誤差が大き くなる. 限界値は構造の熱応力特性に依存し, Green 関 数から定めることができる. 時間幅か限界值を超える場 合は分割して計算するのがよい.

\section{3. 適用性の検吋}

\section{1 解析モデル}

3.1.1 全体構造 図 1 に実用高速炉の IHX の全体構造 を示す. 材料は高温強度と熱応力特性に優れた $12 \mathrm{Cr}$ 系 鋼である.内筒に主循環ポンプが組み込まれ，内筒と外 
筒のアニュラス部か爇交換器で, 外筒はスカート構造で 支持される. アニュラス部は上から，一次系 $\mathrm{Na}$ 入口プ レナムおよび上部管板, 管束部伝熱領域および二次系 $\mathrm{Na}$ 出口アニュラス, 下部管板および一次系 $\mathrm{Na}$ 出口プ レナム, 二次系 $\mathrm{Na}$ 入ロアニュラスとなっている. 本報 では熱過渡応力が厳しい IHX のスカート構造と上部管 板構造を対象として提案手法を用いた評価を行った.

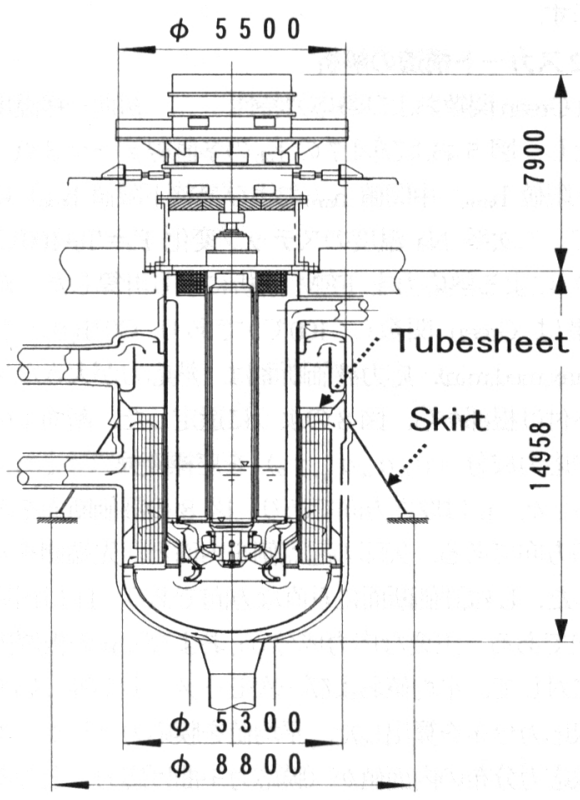

Fig. 1 Structures of IHX

3.12 スカート構造 図 2 にスカート構造の解析モデ ルを示す. 外筒内面は一次系出口側 $\mathrm{Na}$ と熱伝垟状態に ある. 二次系 $\mathrm{Na}$ 温度を $\mathrm{F} 2(\mathrm{t})$ とし, 熱伝達係数を $\mathrm{h}_{2}(\mathrm{t})$ と する. スカート下部の外面は雾囲気と熱伝達状態にある。 雾囲気温度を $\mathrm{T}_{0}=50^{\circ} \mathrm{C}$ とし, 熱伝達保数を $\mathrm{h}_{0}=45 \mathrm{~W} /$ $\mathrm{m} 2 \mathrm{~K}$ とした. $\mathrm{T}_{0}$ を熱応力 0 の基準温度とし, 本部位を 単一流体の温度およひ熱伝達係数が変化する構造として モデル化した.

3.1 .3 管板構造 図 3 に管板構造の解析モデルを示す. 上部プレナムの内筒外面，外筒内面，管板上面および管 板支持スカート上面は一次系入口側 $\mathrm{Na}$ と熱伝達状態に ある. 一次系 $\mathrm{Na}$ 温度を $\mathrm{F}_{1}(\mathrm{t})$ とし, 熱伝详係数を $\mathrm{h}_{1 \mathrm{a}}(\mathrm{t})$ と する. 管板を貫通する伝熱管内面も一次系 $\mathrm{Na}$ と熱伝達 にあり，熱伝達係数を hwb (t) とする．管束部伝熱領域の 内筒外面およひ管板下面は一次系出口側 $\mathrm{Na}$ と熱伝達状 態にある. 二次系 $\mathrm{Na}$ 温度を $\mathrm{F} 2(\mathrm{t})$ とし, 熱伝達係数を he $(t)$ とする. 管板支持スカート下面および外筒内面も二 次系 $\mathrm{Na}$ と熱伝達状態にあり, 熱伝達係数を has $(t)$ とする.
F $2(t)$ および h $b(t)$ はスカート構造と共通である. 他の表面 は断熱とする. 雾囲気温度と熱伝達がないので, 熱応力 0 の基淮温度 $\mathrm{T} 0$ は任意でよい. 本部位を 2 流体の温度お よひ熱伝達係数が変化する構造としてモデル化した. 2 流体について, それぞれ 2 つ部分表面毎に, 合計 4 種 類の熱伝達係数を与えた.

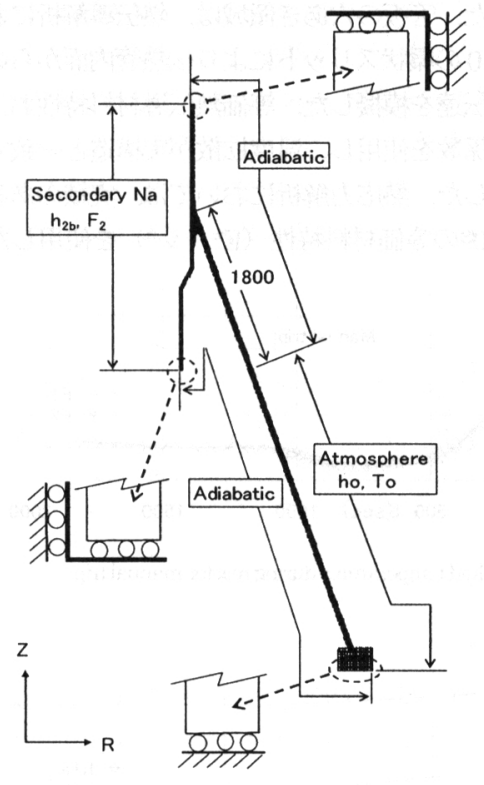

Fig. 2 Analysis model of skirt-structure

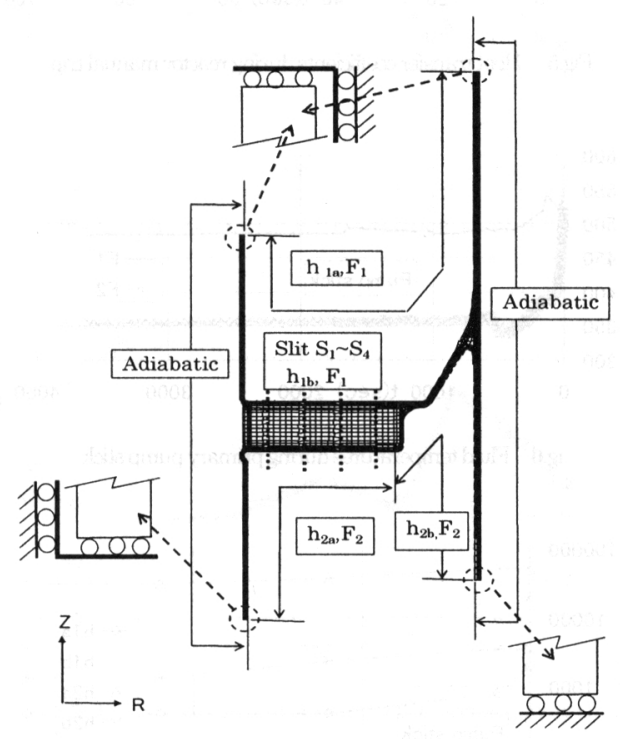

Fig.3 Analysis model of tube-sheet structure 
3.1.4 材料特性その他 材料特性は温度変動範囲のほ ぼ中間 $450^{\circ} \mathrm{C}$ における $12 \mathrm{Cr}$ 系鋼の值を用いた. 密度 $\rho$ $=7780 \mathrm{~kg} / \mathrm{m}^{3}$, 比熱 $\mathrm{C}=657 \mathrm{~J} / \mathrm{kgK}$, 熱云導率 $\lambda=29 \mathrm{~W} /$ $\mathrm{mK}$, ヤング率 $\mathrm{E}=1.85 \times 10^{5} \mathrm{MPa}$ ，ポアソン比 $\nu=0.298$, 線膨張係数 $\alpha=1.3 \times 10^{-5} /{ }^{\circ} \mathrm{C}$

解析コードは FINAS - v13.0かを使用し, 軸㸚称 4 節 点要素を用いた。管板の穴あき領域は，熱伝導解析にお いては，隙間 0 の環状スリットにより伝熱管内面からの 半径方向の熱伝達を模擬した. 等価熱伝導材料特性およ び等価熱伝達保数を使用し、温度拡散が実構造と一致す るように設定した. 熱応力解析においては，実績のある

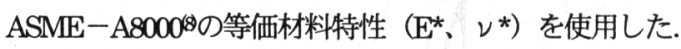



Fig. 4 Fluid temperatures during reactor manual trip

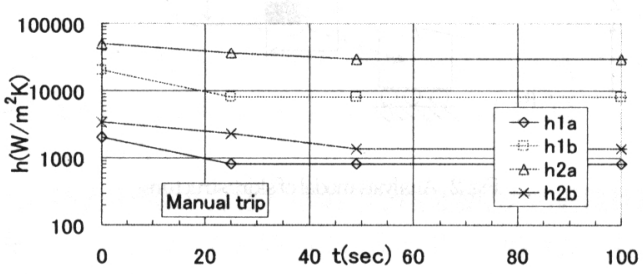

Fig.5 Heat transfer coefficients during reactor manual trip



ig.6 Fluid temperatures during primary pump stick

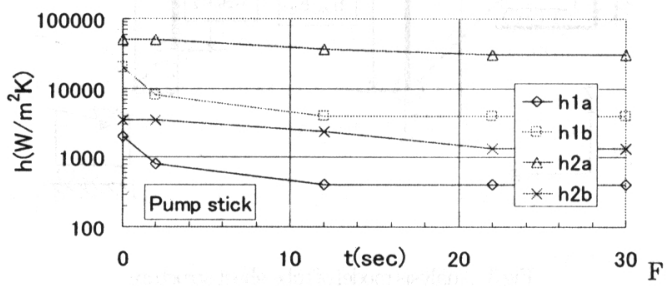

ig.7 Heat transfer coefficients during primary pump stick
3.1 .5 熱過渡事象 $\quad F B R$ 構造設計で想定される代表 的な熱過渡事象として原子炉の手動トリップ事象と主循 環ポンプの軸固着事象を取り扱うことにする. 手動卜リ ップ事象による一次系 $\mathrm{Na}$ 温度および一次系 $\mathrm{Na}$ 温度の 時間変化を図 4 に, 多直線近似した熱伝達保数の時間変 化を図 5 に示す. 軸固着事象による Na 温度の時間変化 を図 6 に, 多直線近似した熱伝垟係数の時間変化を図 7 に示す.

\section{2 スカート構造の解析}

321 Green 関数およひ熱応力特性初期一様温度を $\mathrm{T}_{0}$ とし, 図 5 およひ図 7 の $\mathrm{h}_{\boldsymbol{b}}$ の多直線デー夕 3 点〔初 期上限値 $h_{\text {max }}$ 中間值 $h_{\text {med }}$ および最終下限值 $h_{\text {min }}$ にに対 して, 二次系 $\mathrm{Na}$ 温度のステップ変化 $\mathrm{F}_{2}=\mathrm{T}_{0}+100^{\circ} \mathrm{C}(\mathrm{t}$ $>0 ）$ による熱応力を FEM 解析により計算した. 解析 結果は Green 関数 $\left(/ 100^{\circ} \mathrm{C}\right)$ であり $\mathrm{G}\left(\mathrm{P}, \mathrm{h}_{\mathrm{j}} \mathrm{t}\right)$ と表す (jemax,med,min). 応力評価断面は, 熱応力が大きなス力 一ト付け根部から, 図 8 のように選定した. 断面上の各 点の応力成分 $\left(\sigma_{\mathrm{r},} \sigma_{\mathrm{Z}} \sigma_{\theta}, \tau_{\mathrm{r}}\right)$ を座標変換 $\left(\sigma_{\mathrm{n}}, \sigma_{\mathrm{L}}, \sigma_{\mathrm{H}}\right.$, $\tau_{\mathrm{nI}}$ した. $\mathrm{n}$ は厚さ方向であり, 図 8 の評価断面を表す 矢印方向である. 矢印の起点側を内面と, 先端側を外面 とした. L は評価断面に垂直な方向であり, $\mathrm{H}$ は円周 $\theta$ 方向である. 主要な応力成分 $\sigma_{L}$ および $\sigma_{\mathrm{H}}$ の板厚内分 布に対して, 平均値および一次モ一メントか等しい等価 直線応力分布を算出した. 平均值を膜応力とした. 等価 直線応力分布の内面值が (膜応力十曲げ応力) となるよ うに曲げ応力を定めた。



Fig.8 Stress evaluation cross-section of skirt-structure

断面 $\mathrm{L}_{\mathrm{R}}$ の $\mathrm{G}\left(\mathrm{L}_{\mathrm{L}} \mathrm{h}_{\max } \mathrm{t}\right)$ を図 9 に示す. 上図は $\sigma_{\mathrm{L}}$ の内面 値, 外面值および曲げ応力値を表す. 下図は $\sigma_{\mathrm{H}}$ の内面 值, 外面値, 膜応力值および曲げ応力值を表わす. 断面 Leでは約 20 秒で極值となる短期熱応力と約 500 秒で極 值となる中期熱応力が現れ, 定常熱応力に収束する. 
$h_{\text {med }}$ および $h_{\text {min }}$ に対する図は省略したが，短期熱応力は 熱伝達係数に大きく依存し，中期および定常熱応力は熱 伝達係数にほとんど依存しない。

断面 $\mathrm{L}_{B}$ の $\mathrm{G}\left(\mathrm{L}_{Q}, \mathrm{~h}_{\text {max }} \mathrm{t}\right)$ を図 10 に示す. 熱伝達表面がな い断面では短期熱応力は小さい. 容器同内面側から温度 変化が進行し, 胴側 (断面 Le, 板厚 $40 \mathrm{~mm}$ ) で板厚方 向温度分布が生じ（曲げ+ピーク型の）短期熱応力が表 れる. 厚肉部（図 8 の破線断面，最大板厚 $112 \mathrm{~mm}$ ）は 温度追従か洋孔，胴側と板厚平均温度差が生じ，半径方 向熱膨張差による (円周方向膜応力十軸方向曲げ型の) 中期熱応力が生じる. スカート下部が低温霩囲気と熱卮 達にあるので, 厚肉部が高温定常值に達した後, 断面 L $\mathrm{L}_{3}$ 下方に大きな軸方向温度分布が形成される．軸方向温 度分布が定常に達して定常熱応力となる.
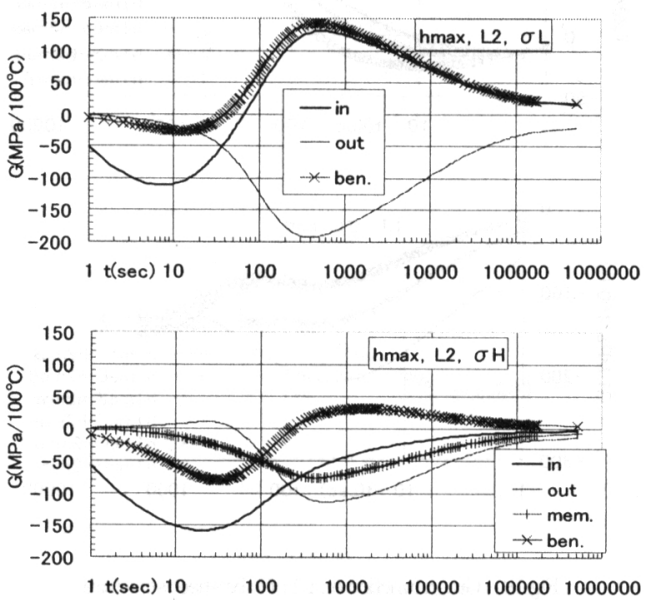

Fig.9 Green function on L2 of skirt-structure
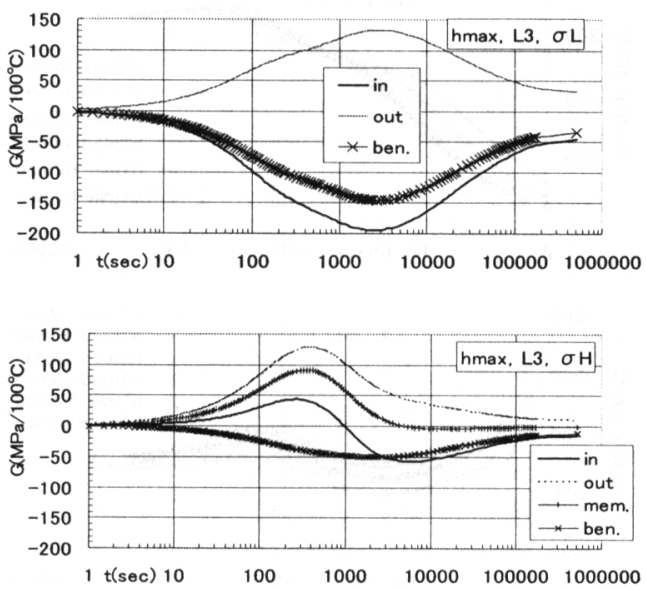

Fig.10 Green function on L3 of skirt-structure
322 検証解析 1 原子炉の手動トリップ事象について, 図 4 の二次系 $\mathrm{Na}$ 温度変化 Fr (t)および Fig.5 の熱伝详係 数の変化 hos $(\mathrm{t}$ ( を模擬した倸数变化 FEM 解析を行った. 断面 Le， L 3 の内表面の Mises の等価応力を図 11, 図 12 に SRef として示した. 上限熱仁達俰数 $\mathrm{h}_{\text {max }}$ を維持した 場合の計算結果〔(1)式において $\mathrm{G}\left(\mathrm{P}, \mathrm{h}_{\text {mex, }}, \mathrm{t}\right)$ を使用した計 算, 上限係数 FEM 解析と同じ結果となる] を Shmax として同図に示した，提案の近似計算法による計算結果 〔(5)式において 3 点の Green 関数を線形補間して計算] を Shvar として同図に示した. 提案手法は係数変化 FEM 解析を良好に模擬している. また上限係数 FEM 解析は安全側の過大評価となった.



Fig.11 Stresses at inner surface of $L 2$ by reactor manual trip



Fig.12 Stresses at inner surface of L3 by reactor manual trip

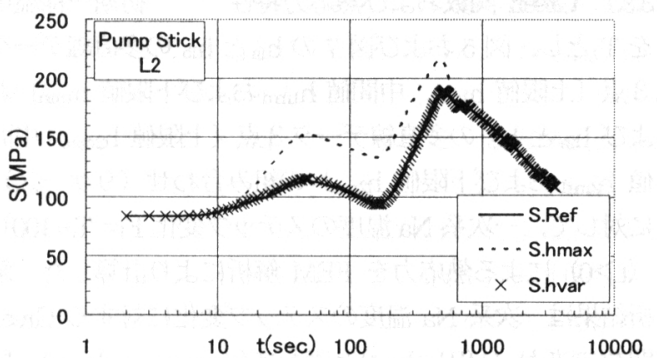

Fig.13 Stresses at inner surface of $L 2$ by primary pump stick 


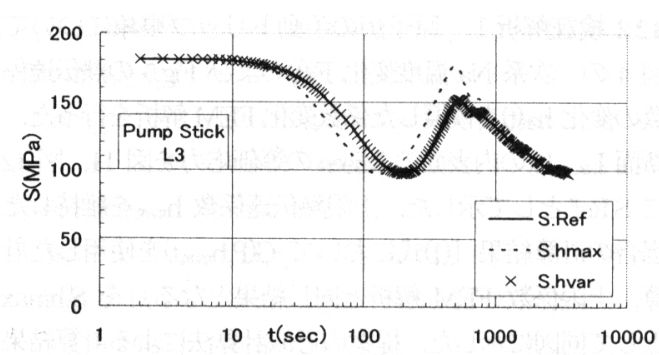

Fig.14 Stresses at inner surface of L3 by primary pump stick

323 検証解析 2 主循環ポンプの軸固着事象について 図 6 の二次系 $\mathrm{Na}$ 温度変化 $\mathrm{F} 2(\mathrm{t})$ およひ図 7 の熱伝详係数 の変化 hos (t) 模擬した係数変化 FEM 解析を行った. 断 面 Le， L 3 の内表面の Mises の等価応力を図 13, 図 14 に SRef として示した. 上限熱伝達保数 hazmax が維持される とした上限倸数 FEM 解析の結果を Shmax として同図 に示した. 提案の近似計算法による結果を Shvar とし て同図に示した. 検証解析 1 と同様に提案手法は係数変 化 FEM 解析を良好に模擬しており, 上限俰数 FEM 解 析は安全側の過大評価となった.



Fig.15 Stress evaluation cross-section of tube-sheet structure

\section{3 管板構造の解析}

3.3.1 Green 関数およひ䓡応力特性 初期一様温度 を $\mathrm{T}_{0}$ とし, 図 5 およひ図 7 の $\mathrm{h}_{\mathrm{la}}$ と $\mathrm{h}_{\mathrm{lb}}$ の多直線デー夕 3 点 (上限值 $h_{1 \text { max }}$ 中間值 $h_{1 \text { med }}$ および下限值 $h_{1 ! m i n}$ ) お

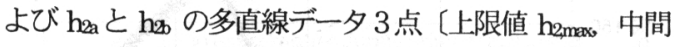
值 hemed および下限值 hamin の組み合わせ（9ケース） に対して, 一次系 $\mathrm{Na}$ 温度のステッフ変化 $\mathrm{F}_{1}=\mathrm{T}_{0}+100^{\circ} \mathrm{C}$ $(\mathrm{t}>0)$ による熱応力を FEM 解析により計算した. 解 析結果は一次系 $\mathrm{Na}$ 温度のステップ変化に対する Green 関数であり $\mathrm{G}_{1}\left(\mathrm{P}, \mathrm{h}_{\mathrm{l}_{\mathrm{j}}} \mathrm{h}_{2 \mathrm{k}, \mathrm{t}} \mathrm{t}\right)$ と表わす $(\mathrm{j}, \mathrm{k}-\mathrm{k}$-max,med,min). 同 様に二次系 $\mathrm{Na}$ 温度のステップ変化 $\mathrm{F}_{2}=\mathrm{T}_{0}+100^{\circ} \mathrm{C}$ （t> 0）による熱応力を FEM 解析により計算した. 解析結 果は一次系 $\mathrm{Na}$ 温度のステップ変化に対する Green 関数 であり $\mathrm{G}_{2}\left(\mathrm{P}, \mathrm{h}_{1, j}, \mathrm{~h}_{2 \mathrm{k}, \mathrm{t}}\right)$ と表す $(\mathrm{j}, \mathrm{k}-\mathrm{max}, \mathrm{med}, \mathrm{min})$. 応力評価
断面は熱応力が大きくなる部位から図 15 のように選定 した. 断面 $\mathrm{L}_{1}$ の外面（プレナム側）における断面に垂 直な応力成分 $\sigma_{\mathrm{L}}$ を図 16 の上段および下段に示す. 断面 L 2 の外面（管束部伝熱領域側）における $\sigma_{\mathrm{L}}$ をそれぞれ 図 17 の上段および下段に示す.

一次系 $\mathrm{Na}$ に接する $\mathrm{L}_{1}$ では $\mathrm{G}$ による一次側内筒の板 厚方向温度分布による（曲げ+ピーク型の）短期熱応力 が大きい. 二次系 $\mathrm{Na}$ に接する Leでは $\mathrm{G}_{2}$ による二次側 内筒の板厚方向温度分布による (曲げ+ピーク型の) 短 期熱応力が大きい.


Fig.16 Green function on L1 of tube-sheet-structure
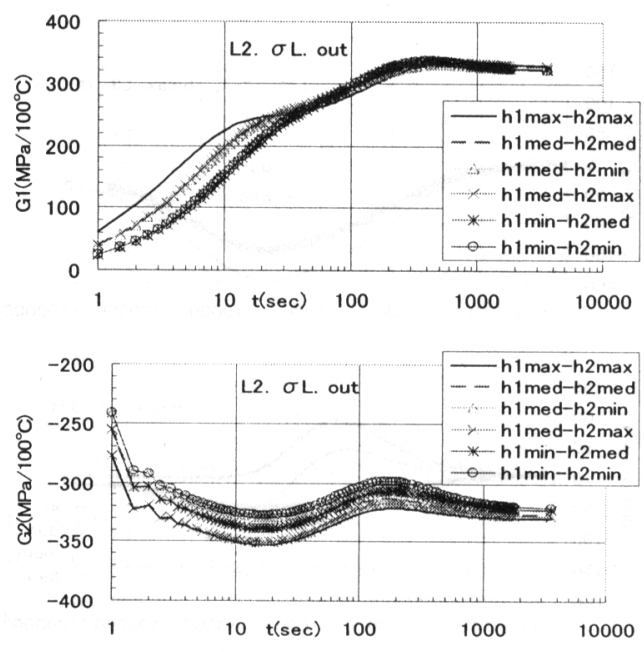

Fig.17 Green function on L2 of tube-sheet-structure 
断面 L およひ断面 L 方向曲げ応力型の) 定常熱応力は, 管板との平均温度差 および管板の上下温度差が支配要因となり， $\mathrm{G}_{1}$ と $\mathrm{G}_{2}$ と は符号が反対で大きさか等しい.

断面 Le は一次系に接しないが，伝熱管内面からの熱 伝達で管板穴あき領域の平均温度が短期に応答するので $\mathrm{G}_{1}$ では短期熱応力がかなり大きい. $\mathrm{G}_{1}$ および $\mathrm{G}_{2}$ とも短 期熱応力は $h_{1}$ および $h_{2}$ の増加で大きくなる. 中期およ び定常熱応力では様相が異なり, 断面 L 1 では $\mathrm{h}_{1}$ の増加 が反対面側の $\mathrm{F}_{2}$ 変化による管板の温度変化を減少させ, $\mathrm{G}_{2}$ を小さくする効果がみられ，同様に断面 $\mathrm{L}_{\mathrm{e}}$ では $\mathrm{h}_{2}$ の 増加が $\mathrm{G}$ を小さくする効果がみられる. これらを「熱 応力緩和効果」と記すことにする.

断面 L $\mathrm{L}_{B}$ の内面（上面, 上部プレナム側）の G および $\mathrm{G}_{2}$ で表わした $\sigma_{\mathrm{L}}$ をそれぞれ図 18 の上段および下段に 示す. 上面(in)が一次系 $\mathrm{Na}$ に接し下面(out)が二次系 $\mathrm{Na}$ に接する L 熱応力とも $\mathrm{G}_{1}$ と $\mathrm{G}_{2}$ とで符号が反対で大きさがほぼ等し い.


Fig.18 Green function on L3 of tube-sheet structure

3.32 検証解析 1 原子炉の手動トリップ事象につい て図 4 の Na 温度の変化およひ図 5 の熱伝達係数の変化 を模擬した係数変化 FEM 解析を行った. 断面 $\mathrm{L}, \mathrm{L}_{2}$ の 外面の Mises の等価応力を図 19 , 図 20 に示す. 係数変 化 FEM 解析結果は SRef として示した. 上限熱伝達係 数 $h_{1 \text { max }}$ および h $h_{\text {max }}$ を維持する上限係数 FEM 解析〔(1)

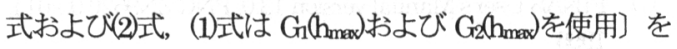
Shmax として同図に示した. 提案の近似計算法による 計算結果〔(5)式および(2)式，(5)式は $3 \times 3$ 点の Green 関 数を線形補間〕を Shvar として同図に示した. (1)式お よび(5)式の積分時間幅の上限值は Green 関数の短期極值
時間以下とし, 全断面で $10 \mathrm{sec}$ とした. (5)式の初期定常 熱応力項の時定数は Gren 関数力短期熱応力から中期熱 応力に移行する時間とし, 断面 $\mathrm{L}_{1}, \mathrm{~L}_{2} \mathrm{I}_{3}$ に対し $\tau$ $\mathrm{p}=200,30,30 \mathrm{sec}$ とした. 提案手法は係数変化 FEM 解析を 良好に模擬している. また上限係数 FEM 解析は断面 L では安全側となったが，断面 LQ および L は非安全側となった. 手動トリップ事象では $\mathrm{F}_{1}$ 変化が $\mathrm{F}_{2}$ 変化より少し大きく, 前述の「熱応力緩和効果」が断 面 Leおよび LBで僅かに優勢に現れたものと考えられる. 上限係数 FEM 解析が複数流体系の場合には応力を過小 評価する場合があることを示している.



Fig.19 Stresses at outer surface of L1 by reactor manual trip

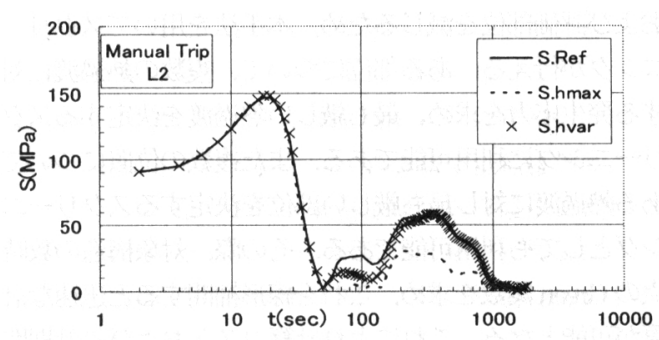

Fig.20 Stresses at outer surface of $L 2$ by reactor manual trip

3.3.3 検就解析 2 主循環ポンプの軸固着事象につい て図 6 の Na温度の変化および図 7 の熱伝澾係数の変化 を模擬した係数変化 FEM 解析を行った. 断面 $\mathrm{L}, \mathrm{L}_{2}$ の 外面の Mises の等価応力を図 21, 図 22 に示す. 保数変 化 FEM 解析を SRef として示した. 上限熱伝垟倸数 h!max および hermax を維持する上限係数 FEM 解析を Shmax として同図に示した. 提案手法による計算結果 を Shvar として同図に示した. 提案手法は倸数変化 FEM 解析を良好に模擬している. 上限倸数 FEM 解析 は検証解析 1 とは逆に, 断面 L 1 で非安全側となり, Le および $\mathrm{L}_{B}$ で安全側となった. 軸固着事象では $\mathrm{F}_{2}$ 変化が $\mathrm{F}_{1}$ 変化より大きく, 前述の「熱応力緩和効果」が断面 L1で優勢に現れたと考えられる. 




Fig.21 Stresses at outer surface of L1 by primary pump stick

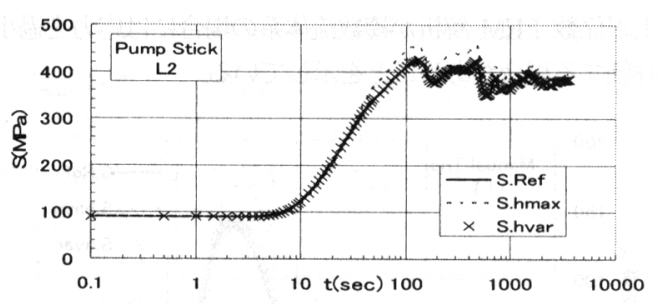

Fig.22 Stresses at outer surface of $L 2$ by primary pump stick

\section{4提案手法の応用可能性}

3.4 .1 熱過渡応カスクリーニング＼cjkstart設計で想定する熱 過渡荷重は種類が多く, 評価部位も複数である. 全てに 対して係数変化 FEM 解析を行うのは, 計算コストおよ ひ設計期間の面で現実的でない. 対象となる熱過渡荷重 および評価部位を減じるため, 本手法を用いてスクリー ニングが行える. ある部位について、複数の熱過渡に対 する発生応力を求め、最も厳しい熱過渡を決定するスク リーニングに利用可能である. また複数の位置について, ある熱過渡に対し最も撖しい部位を決定するスクリー二 ングとしても利用可能である. その際, 対象構造の数時 点の Green 関数を求め, これを線形補間すると迅速な計 算が可能となる.これにより計算コストおよひ設計期間 の短縮が期待できる.

3.4. 熱過渡応力オンライン評価運転中の原子力発電 プラントでは主要な位置で泠却材流量, 温度などの運転 データが常時計測されている. 設計時に Green 関数を作 成してデータベース化し，これを参照することにより， 主要な部位の熱過渡応力をオンライン評価することがで きる. 運転補修計画あるいは疲労破壊防止などに役立て ることが期待できる.

3.4.3熱過渡応力シミュレーションプラント動特性計 算コードあるいは運転デー夕と提案手法を併用すること により, 原子力プラントの運転条件変更, 異常時の停止 手順あるいは計画的出力変更など, 様々な事象に対応し て, 主要部位の熱過渡応力および疲労損傷を迅速に評価
する.これにより, 運転条件あるいは異常事象に対しど のように対処するのが良いかをシミュレーションできる. 安全を維持しつつ運転効率を上げる最適運転条件の追求 などが可能となると思われる.

\section{4. 結 言}

全体を通じ，得られた結論は以下の通りである. (1)定俰数の線形熱応力における Green 関数法を、熱伝達 係数が変化する熱心力問題に適用するための近似評価法 を提案した.

(2)高速炉の IHX のスカート構造と管板構造の熱過渡応 力を提案手法により計算し, 保数変化 FEM 解析および 上限係数 FEM 解析と比較した. 上限係数 FEM 解析は, スカート構造のような単一流体系では過大評価となる場 合が多く, 管板構造のような複数流体系では過小評価と なる場合があることを確認した. 提案手法は, 単一流体 系と複数流体系の双方に対し, 倸数変化 FEM 解析をよ く近似できることを確認した。

(3)提案手法は熱過渡応力スクリーニング, 熱過渡応力の オンライン評価あるいはシミュレーションなどに活用で き, プラントコスト低减への寄与が期待できる.

本研究はサイクル機構における研究として, また,

一部は経済産業省受託研究の一睘として実施した。

$$
\text { 文献 }
$$

(1) Furuhashi, I. et al, Development of thermal stress screening method (Application of Green function method), JNC TN9400 2004-013,Jan,2004

(2) Mukhopadhyay, N. K et al, On line fatigue monitoring methodology for power plant components, IJPVP 60(1994), pp297-306.

(3) Sugano, Y., Analytical Solutions of Transient Temperature and Thermal Stress in a Circular Plate with Arbitrary Variation of Heat-Transfer Coefficient, Transactions of the Japan Mechanical Engineers, Series A, Vol67, No.655(2001), pp.542-548.

(4) Lee, H-L et al, Transient Thermoelastic Analysis of an Annular Fin with Coupling Effect and Variable Heat Transfer Coefficient, J Thermal Stresses, Vol.25, No.12(2002), pp.1105-1120.

(5) Furuhashi, I. and Kasahara, N., Development of thermal stress evaluation method (Application to variable heat transfer problems), PNC PN9400 93-198, 1993.

(6) Carslaw, H. S. and Jaeger, J. C., Conduction of heat in solids, second edition. Clarendon Press, Oxford, 1959

(7) FINAS User's Manual version 13.0, PNC ZN9520 95-014, 1995

(8) ASME Boiler and Pressure Vessel Code, 1995, SectionIII, Division I , ASME, New York 